\title{
Kurumsal Yönetim Üzerine Bir Yazın Taraması
}

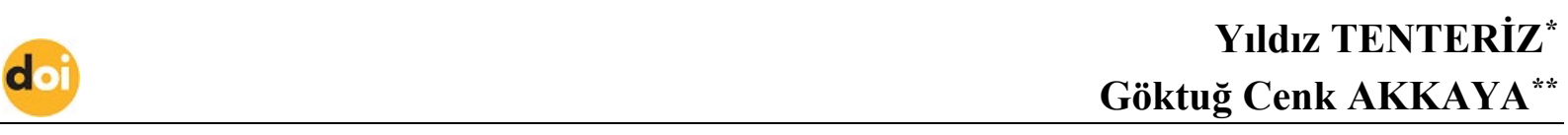

\section{Öz}

Kurumsal yönetim; gittikçe önem kazanan ve yazında çalışmaların arttı̆ğ görülen konulardan biridir. Bu çalışmada kurumsal yönetim, kurumsal yönetim ile ilgili teoriler ve ilgili ilkelere ilişkin bilgi verildikten sonra yerli ve yabancı yazında kurumsal yönetim üzerine yapılmış çalışmalara yönelik bir yazın taraması sunulmuştur. 2000-2021 yılları arasında akademik dergilerde yer alan çalışmaları kapsayan tarama sonucunda araştırma kapsamındaki çalışmaların önemli bir kısmının yurt dışında yapılmış olduğu görülmüştür. Özellikle son üç yılda yurt içinde yayınlanan çalışmalarda kurumsal yönetimi ele alan yayın sayısının artış gösterdiği gözlenmiş̧tir. Yabancı yazında yapılan çalışmaların sayısı bazı yıllarda düşüs gösterse de son on yılda konunun daha fazla ele alındı̆̆ görülmektedir. Çalışmanın alan yazına kurumsal yönetim ile ilgili olarak yerli ve yabancı yazında yapılan çalışmaların konu ve çalışma sayısı eğiliminin ortaya koyulması açısından katkıda bulunduğu ifade edilebilmektedir. Bununla birlikte, yerli yazında yapılan çalışmaların sadece bir adet ulusal veritabanında yayınlanan makalelerden, yabancı çalışmaların ise sadece bir adet uluslararası veritabanında yayınlanan makalelerden seçilmesi çalı̧̧manın kısıtını oluşturmaktadır. Ayrıca uluslararası veritabanında kurumsal yönetim ile ilgili çalışmaların oldukça fazla olması nedeniyle çalışmanın kapsamıyla ilgili olarak anahtar kelimelerle kisitlanmıştır.

Anahtar Kelimeler: Kurumsal yönetim, kurumsal yönetim ilkeleri, yazın taraması.

\section{A Literature Review of Corporate Governance}

\begin{abstract}
Corporate governance is one of the most important issues in the literature, with an increasing number of studies in the literature. In this study, after giving information about corporate governance, theories about corporate governance and related principles, a literature review on studies on corporate governance in domestic and foreign literature is presented. As a result of the scanning covering the studies in academic journals between 2000 and 2021, it was seen that a significant part of the studies within the scope of the research were done abroad. It has been observed that the number of publications dealing with corporate governance has increased, especially in studies published in Turkey in the last three years. Although the number of studies in foreign literature has decreased in some years, it is seen that the subject has been discussed more in the last ten years. It can be stated that the study contributes to the literature in terms of revealing the trend of the subject and number of studies in the domestic and foreign literature on corporate governance. However, the limitation of the study is that the studies in the domestic literature are selected only from the articles published in the national database, and the foreign studies are only selected from the articles published in an international database. In addition, due to the large number of studies on corporate governance in an international database, the scope of the study was limited to keywords.
\end{abstract}

Keywords: Corporate governance, corporate governance principles, literature review.

\footnotetext{
* ORCID Doktora Öğrencisi, Dokuz Eylül Üniversitesi, İ̈BF, İşletme Bölümü, yildiztenteriz@hotmail.com

** ORCID Prof. Dr., Dokuz Eylül Üniversitesi, İ̈BF, İşletme Bölümü, cenk.akkaya@deu.edu.tr
} 
As a result of the effect of globalization and the increasing complexity of the business world, it can be said that there is more confidence in the private sector as the effect of growth in both developed and developing countries. Companies appear as legal entities and created by societies because they are an effective form of organization and society benefits from their existence. Companies contribute to economic growth and development. Thus, this leads to improved living standards and poverty reduction. The final result of all this is the creation of more stable political systems (Mohamad, 2004: 3). This brings the concept of corporate governance.

Corporate governance is becoming an important strategy for sustainable growth and development, especially for large and medium-sized enterprises in the world and Turkey. For economic growth, it is necessary for existing companies to increase the number of employees and to implement new practices that will create a competitive advantage to extend their shortened lives (Yavuz et al., 2015: 80-81). Considering the role of corporate governance in the growth and development of countries, not only in terms of businesses, it can be stated that its importance is undeniable and its importance has increased gradually in recent years (Pamukçu, 2011: 146).

In current research was carried out on the articles on corporate governance in Turkey and abroad between the years 2000-2021. For this purpose, articles in academic journals in a national database in Turkey and international databases were scanned. Due to the wide scope of the foreign studies, the search was carried out by restricting it to keywords. Within the scope of the study, 117 Turkish and 361 foreign studies were included as a result of the search covering the studies in academic journals between 2000 and 2021.

As a result of the research, it was seen that keywords such as corporate governance index, BIST, financial performance, corporate governance principles, internal audit, firm performance, corporate social responsibility are discussed, in foreign literature, stock market, stock return rate, stocks, and commodity exchanges, stock prices, CEO keywords such as shareholders, consumer credit, shareholders and financiers, financial performance, investment banking, and securities transactions, portfolio management, mergers and acquisitions, and organizational performance were seen to be covered more. Based on this information, it is seen that financial performance and firm performance are the concepts that are mostly discussed in common. It can be interpreted that foreign literature mostly includes concepts such as mergers and acquisitions and commodity exchanges, stock prices, investment banking, and securities transactions, unlike the domestic literature.

However, the limitation of the study is that the studies in the domestic literature are selected only from the articles published in the national database, and the foreign studies are only selected from the articles published in the international database. In addition, due to a large number of studies on corporate governance in the international database, the scope of the study was limited to keywords. 


\section{Giriş}

Küreselleşmenin etkisi ve iş dünyasının giderek artan karmaşıklığının bir sonucu olarak hem gelişmiş hem de gelişmekte olan ülkelerde büyümenin etkisiyle özel sektöre daha fazla güven duyulduğu söylenebilmektedir. Şirketler, etkin bir örgütlenme biçimi oldukları ve toplumun onların varlığından yararlanması sebebiyle toplumlar tarafından oluşturulmuş, yaratılmış tüzel kişilikler olarak karşımıza çıkmaktadırlar. Şirketler, ekonomik büyümeye ve kalkınmaya katkıda bulunmaktadır. Böylelikle, bu durum yaşam standartlarının iyileştirilmesine ve yoksulluğun azaltılmasına neden olmaktadır. Tüm bunların nihai sonucu ise daha istikrarlı siyasi sistemlerin yaratılmasıdır (Mohamad, 2004: 3). Bu da kurumsal yönetim kavramını getirmektedir.

Kurumsal yönetim, özellikle büyük ve orta ölçekli işletmelerin Dünyada ve Türkiye'de sürdürülebilir büyüme ve gelişmedeki önemli stratejisi haline gelmektedir. Ekonomik anlamda büyüme için mevcut şirketlerin istihdam sayılarını artırmasına, kısalan ömürlerini uzatmak için rekabet avantajı yaratacak yeni uygulamalarda bulunmalarına ihtiyaç duyulmaktadır (Yavuz vd., 2015: 80-81). Kurumsal yönetime sadece işletmeler açısından değil ülkelerin büyüme ve gelişmesindeki rolü açısından bakıldığından öneminin yadsınamaz olduğu ve son yıllarda da öneminin giderek arttığı ifade edilebilmektedir (Pamukçu, 2011: 146).

Şirketlerin performansları konusunda şeffaf bilgi sunmalarının sorumluluğu, şirketlerin hisse senetlerini halka arz ederek ya da tahvil ihraç ederek kaynak sağlamak amacıyla sermaye piyasalarına yönelmektedirler. Bunun sonucunda öncelikle hissedarlar ve borç verenler olarak bütün çıkar gruplarını getirmiştir. Şirketlerin faaliyet sonuçlarına ilişkin bilgileri paylaşması menfaat sahipleri, grubunun tüm üyeleri, potansiyel yatırımcılar açısından kontrol ve karar verme süreçleri nedeniyle yeterli olmamaktadır (Tekbaş ve Güzeldere, 2015: 14). Bu bilgiler uluslararası düzeyde kabul gören muhasebe ve denetim standartlarına uygun olarak hazırlanmalı ve yıllık olarak gerçekleştirilen bağımsız denetime tabi tutulmalıdır. Uluslararası kabul görmüş muhasebe standartlarının kullanılması, karşılaştırılabilirliği artıracak ve hem yatırımcılara hem de analistlere kurumsal performansı ve göreceli değerlerine göre karar vermelerini karşılaştırmada yardımcı olacaktır. Aynı şekilde hisse sahipliği, oy hakları, yönetim kurulunun kimliği gibi şirket yönetimine ilişkin bilgiler üyeler, kilit yöneticiler ve yönetici maaşları da şeffaflığın kritik bir bileşenidir (Mohamad, 2004; 8). Bu bağlamda kurumsal yönetimin önemi söz konusu olmaktadır.

Yazın incelendiğinde; Kurumsal yönetim kavramının yerli ve yabancı pek çok araştırmaya konu olduğu görülmektedir. Kurumsal yönetim ile ilgili son zamanlarda araştırmaların daha da artması kavramın çoğunlukla hangi konularla ele alındığını, yerli yabanc1 yazındaki eğiliminin ne olduğunun görülmesi bu çalışmanın konusunun belirlenmesinde etkili olmuştur. Bu nedenle giriş bölümünden sonra ikinci bölümde kurumsal yönetim kavramına yer verilmiş, üçüncü bölümde kurumsal yönetimin gelişiminde rol oynayan kurumsal yönetime ilişkin teoriler üzerinde durulmuştur. Dördüncü bölümde kurumsal yönetim ilkelerine beşinci bölümde ekonomik iş birliği ve kalkınma örgütü (OECD) kurumsal yönetim ilkelerine ve altıncı bölümde SPK kurumsal yönetim ilkelerine yer verilmiştir. Yedinci bölümde ise yazın taraması bulguları ortaya konmuştur.

\section{Kurumsal Yönetim Kavramı}

Kurumsal yönetim kavramı çok çeşitli şekillerde tanımlanabilir olmasının yanı sıra iki kategoriye girme eğilimindedir. Bu kavram ilk kategoride performans, büyüme, finansal yap1, verimlilik, hissedarlara ve diğer paydaşlara davranış gibi ölçütler açısından şirketlerin gerçek davranışları olan bir dizi davranış modeli olarak tanımlanmaktadır. İkinci kategori olarak ise, 
normatif çerçeveyle, bir diğer ifade ile hukuk sistemi, yargı sistemi, finansal piyasalar ve faktör (emek) piyasaları gibi kaynaklardan gelen kurallarla firmaların faaliyet gösterdiği kurallarla ilgili olarak ifade edilmektedir (Claessens, 2006: 93).

Şirket içindeki düzeni ve şirketin karlılığını arttırmayı sağlayan kurallar bütününü ifade eden kurumsal yönetim kavramı ilk olarak 1990'lı yıllarda ortaya çıkan bir kavramdır. Dünyada İngilizce olarak "corporate governance" şeklinde ifade edilmekte, yerli yazında ise kurumsal yönetişim ve kurumsal yönetim şeklinde çevrilmektedir (Kömeçoğlu ve Vuran, 2018: 705).

Kurumsal yönetimin şirketlerde, üst yönetim, çalışanlar, yönetim kurulları, hakim ortaklar, küçük hissedarlar ve diğer menfaat sahiplerinin çıkarlarını gözetmeyi mümkün kılan, gerekli kontrolleri ve dengeyi sağlayan bir yapı olarak ifade etmek mümkündür (Yavuz vd., 2015: 80).

Kurumsal yönetim kavramı genel bir tanım olarak iyi şirket yönetimi için gerekli formel ve informel kurallar bütünü olarak ifade edilebilmektedir. Dar anlamda ise kavram "iyi şirket yönetimiee anlamına gelmektedir. İyi şirket yönetimi için şirketin üst yönetiminin ve yönetim kurulunun görev ve sorumluluklarının ve şirket içi ve şirket dışı paydaşların haklarının önceden belirlenmesi ve bunların yasal çerçeve içerisine alınması oldukça önemli olmakla beraber yeterli olmayabilmektedir. $\mathrm{Bu}$ nedenle, iyi bir şirket yönetiminde toplam kalite yönetimi, değişim yönetimi, sinerjik yönetim, insan kaynakları yönetimi ve stratejik yönetim gibi yönetim teknik ve ilkelerinin etkili bir şekilde uygulanması gerekmektedir (Aghabaki, 2014: 6).

İyi bir kurumsal yönetimin işletme performansını olumlu yönde etkilediği ifade edilebilmektedir. Çünkü yüksek performans gösteren işletmelere yatırımcılar daha çok ilgi duymaya başlayabilmekte ve bu durumda hisse senetlerinin piyasa değeri artabilmektedir. Bunun sonucu olarak işletmelere olan yatırım düzeyi artmakta ve işletme için geri dönüşüm oranı olumlu olabilmektedir (Karamustafa vd., 2009: 101).

Kurumsal yönetim uygulamaları doğru şekilde hayata geçirildiğinde şirketlere ve ülkelere önemli derecede yararları bulunmaktadır. Kurumsal yönetim kalitesi yüksek olduğunda şirketler açısından finansman imkânları, düşük sermaye maliyeti, likiditenin artması, krizlerin daha kolay aşılmasını ifade etmektedir. Ülkeler açısından ise, iyi kurumsal yönetimin ekonominin ve sermaye piyasalarının rekabet gücünü arttırması, sermayenin yurt dışına kaçmasını önlemesi, ülkenin imajının yükselmesi, krizlerin daha az zararla atlatılması, kaynakların daha etkin bir şeklide dağılması, yüksek refahın sağlanması ve sürdürülmesi gibi durumları ifade ettiği belirtilebilmektedir (Saldanl1, 2012: 144). Bireyler, yatırım/emeklilik fonları, bankalar, finansal kuruluşlar ve hükümetler, şirketlere finansman sağlayanlar, yatırımlarının hem üretken hem de korumalı olduğuna dair güvenceyi şirketlerden istemektedirler. $\mathrm{Bu}$ nedenle etkili kurumsal yönetim, bu güvenceleri sağlamakla ilgili olmaktadir (Mohamad, 2004: 2).

Ayrıca kurumsal yönetim şirketlerin, kurumsal sosyal sorumluluklarını yerine getirmeleri noktasında da önemli bir kavram olarak karşımıza çıkmaktadır. Khan vd. (2013) yönetimsel mülkiyet, yönetim kurulu bağımsızlığı, kamu ve yabancı mülkiyeti, denetim komitesinin mevcudiyeti ve CEO ikiliği gibi kurumsal yönetim ile ilgili özelliklerin farklı paydaş gruplarının örgütsel tepkiyi ne seviyede etkilediğini belirleyebilmek için bir çerçeve benimsendiğini ifade etmişlerdir. $\mathrm{Bu}$ bağlamda şirketlerin kurumsal sosyal sorumluluk açıklamalarının yönetimsel sahiplik ile negatif ilişkisi olmasına karşılık, bu ilişkinin ihracata yönelik endüstriler açısından önemli ve pozitif hale geldiğini belirtmişlerdir. Ayrıca yönetim kurulu bağımsızlığı, denetimin, kamu ve yabancı mülkiyetin önemli etkileri olduğunu ifade etmişlerdir. 
Şeffaflık, hesap verebilirlik ve hissedarlara adil ve hakkaniyetli muamele ile kendini gösteren etkili kurumsal yönetimin, sürdürülebilir kalkınmayı teşvik etme çabalarının ön koşulu olduğuna dair artan bir farkındalık söz konusu olmaktadır. Bu amaçla, kurumsal yönetim iyileştirmelerinin önemi konusunda farkındalığı artırmak ve kurumsal yönetim reformunun uygulanmasına yardımcı olmak için hem kamu (hükümetler tarafindan temsil edildiği şekliyle) hem de özel sektör ortaklığına ihtiyaç olduğu belirtilmektedir (Mohamad, 2004: 9). Kurumsal yönetim kavramı bireyler, finansal kuruluşlar, hissedarlar, paydaşlar gibi birçok kişi ve kurumu etkileyen bir kavram olması sebebiyle öneminin yadsınamaz olduğu söylenebilmektedir. Bu derece önemli kavram olan kurumsal yönetim kavramı yerli ve yabancı yazında birçok teoriye dayandırılmaktadır. Bu nedenle üçüncü bölümde ilgili teoriler üzerinde durulacaktır.

\section{Kurumsal Yönetime İlişkin Teoriler}

$\mathrm{Bu}$ kısımda kurumsal yönetime ilişkin teorilerden vekalet teorisi, paydaş teorisi, hissedar teorisi, işlem maliyeti teorisi ve miyop piyasa teorisine değinilecektir.

\subsection{Vekalet Teorisi}

Kurumsal yönetimin temel sorunu vekalet teorisine dayanmaktadır. Bu bağlamda da şirket sahipleri ve yöneticiler arasında vekalet sorununu ortadan kaldırmaya yönelik bir ilişki ortaya konulması gerekmektedir. Teoride sözleşme olarak adlandırılan işletme içi kurallar, örgüt içinde performans değerlendirilmelerde yöneticinin haklarını, uygulanacak performans kriterlerini ve yöneticilerin elde edilecek gelir sistemlerinin temel olarak şekillendirilmesini kapsamaktadır (Dincer, 2013: 16).

Modern işletmeciliğin ortaya çıkışında, işletmenin sahipliği ile işletmenin yönetsel kontrolü arasında ayrım oluşmaktadır. Profesyonel yöneticilerin giderek artan ekonomik ve yönetsel sorumluluklarını yönlendirebilme yetenekleri ve sahiplerin beklentilerinin ötesinde gelişme kaydedilmesiyle işletmelerde yetki devri kaçınılmaz durumuna gelmektedir. Örneğin, vekalet teorisinde insan modelinde, bireyler kişisel faydayı maksimize etmeyi amaçlayan rasyonel temel üzerine oturtulmuştur (Akın, 2004: 131).

Vekâlet ilişkisi ilk kez 1976 yllında "Theory of the Firm: Managerial Behavior, Agency Costs and Ownership Structure" adlı çalışmalarında Jensen ve Meckling, teori boyutunda incelemişlerdir (Güvençer, 2008: 23).

Vekalet modelinde örgütsel yapı ve ilişkilere göre değerlendirilme yapılmasının yönetici davranışları üzerinde belirleyici olabileceği belirtilmektedir. Karar verme süreçlerinde yetkili olan yöneticilerin uygulamalarının çeşitli yönetsel sorunlara neden olması bu durumun bir sonucu olmaktadır. Örneğin, yöneticilerin psikolojik durumları bir risk unsuru olarak ortaya çıkabilmektedir. Yöneticinin çıarcı bir tutumla kontrolü bırakmak istememesi gibi durumlar ortaya çıkabilmektedir. Böylece bu durumda iki tarafın da beklentilerinin ilişkiler açısından azalmasına neden olmaktadır. Ayrıca bu durum vekalet maliyetlerinin kontrolünü zorlaşmasına neden olmaktadır (Akın, 2004: 133).

Günlük hayatta neredeyse her alanda karşılaşılabilecek bir olgu olan vekâlet ilişkisi, bir kişinin kendi adına işlerini yaptırması amacıyla bir başkasına yetki vermesi sonucu oluşan bir ilişkidir. Ancak bu vekâlet ilişkisi içindeki tarafların farklı çıkarlara sahip olmaları ve bireysel olarak çıkarlarını maksimize etme istekleri gibi durumlar çıkar çatı̧̧aları doğurmakta ve vekâlet sorunlarının ortaya çıkmasına neden olmaktadır. Vekâlet sorunları asilin denetlenmesi gerekliliği nedeniyle önlenemeyen kayıplar, izleme ve bağlanma maliyetleri gibi vekâlet maliyetlerinin oluşmasına neden olmaktadır. Genellikle güven eksikliği sebebiyle oluşan 
vekâlet maliyetlerini azaltabilmek için yöneticiler, kayırmacılığı yönetsel bir araç olarak kullanabilmektedirler (Ekinci, 2017: 88-89).

\subsection{Paydaş Teorisi}

Bir firmanın nihai amacı pay sahiplerinin çıkarlarına hizmet etmektir. Bu görüşün zıttı ise paydaş teorisidir (Özsoy, 2011: 32). Paydaş Teorisi, hissedar kavramıyla ilişkili olarak ampirik önerilerin ve beklentilerin bir çerçevesi olarak kullanılabilmektedir. Böylelikle kurumsal performans ve hissedar yönetimi kavramları arasındaki ilişki incelenebilmektedir (Dincer, 2013: 18).

Pay sahipleri ile paydaşların farklı yönetişim ve denetim mekanizmalarını tercih etmeleri olasıdır. Bahsedilen eserin yayınlamasından bu zamana kadar farklı yönetişim modelleri tartışılmaktadır. Son yıllarda paydaşların çıkarını gözeten yönetişim modellerinin daha da fazla tartışılıp ele alınmasının nedeni firmaların kararlarının farklı paydaş grupları üzerindeki etkisinin zaman zaman pay sahipleri üzerindeki etkisinden daha fazla olabileceği düşüncesidir (Özsoy, 2011: 33).

Emshoff ve Freeman, teorinin ortaya koyduğu iki prensip olduğunu belirtmişlerdir. $\mathrm{Bu}$ prensiplerden ilki işletmenin amacının ne olduğunun belirlenmesidir. Amacın belirlenmiş olması işletmenin ilerlemesine katkı sağlamakta ve işletme performansının iyileşmesine yardımcı olmaktadır. İkinci prensip ise yönetimin paydaşlara karşı olan sorumluluklarının neler olduğunun belirtilmesi olarak ifade edilmektedir. Bu yönetimi amaçlarına ulaşmak için nasıl çalışmak istediği ve şirketin paydaşlarıyla ne gibi ilişkiler kurması gerektiği hakkında düşünmeye sevk ettiği belirtilebilir (Ertuğrul, 2008: 201).

\subsection{Hissedar Teorisi}

Hissedar Teorisi, hissedar fayda maksimizasyonu ile ilgilenen neoklasik iktisat teorisinin altında yatan bir teoridir. Nobel ödüllü Milton Friedman, bu görüşün en önemli temsilcisi olarak ifade edilebilmektedir. Teorinin başlangıç noktası, kaynakların verimli dağılımı konusunda piyasanın her zaman kuruluşlardan üstün olduğu ve yöneticilerin şirketleri hissedarların değil kendi çıkarları lehine yönetebileceği inancıydı. Kurumsal hisse senedi getiri oranı, üstün performansın ölçüsü olarak alındığında ve yöneticilerin ücretleri bu oranı yansıttığında, yöneticilerin firsatçı davranışlarından kaçınılmış olacağ 1 belirtilmektedir. $\mathrm{Bu}$ görüşte hissedarlar müdür, yöneticiler ise bu müdürün temsilcileri olarak görülmektedir. Yöneticinin beklenen rolü, sadece ana çıkarlara hizmet etmesidir (Mele, 2009: 56-57).

Hissedar menfaatlerinin zaman zaman diğer paydaşlardan üstün tutulma durumu zaman zaman işletme içinde ve dişında olan diğer paydaşların menfaatiyle aynı doğrultuda olmayabilmektedir. Ancak kurumsal yönetim anlayışı farklı çıkar gruplarının ihtiyaç ve isteklerini dengeleyebilecektir. Ayrıca kurumsal yönetim anlayışı hissedarlar arasında aynı haklara sahip olma ve sahip olunan bu hakların orantılı bir şekilde uygulanması sağlayacaktır (Tufan, 2018:11).

\section{4. İşlem Maliyeti Teorisi}

İşlem maliyetleri diğer bir ad olarak eksik sözleşmeler olarak adlandırılmaktadır. Sözleşmelerde ana başlıklar belirlenmediğinden ya da belirlenen ana unsurlara uyulmadığından dolayı şirketler işlem maliyetleriyle karşı karşıya kalmaktadırlar. Başka bir açıdan da bilgi maliyetleri özellikle finansal piyasalarda en büyük maliyetler arasında yer almaktadır. Sonuç 
olarak sahiplik paylarının etkin biçimde ayırt edilmesinde işlem maliyetleri azalmaktadır. Toplam maliyetleri düşürmek aynı zamanda işlem maliyetlerini düşürmeye de olanak verecektir (Tufan, 2018: 11). İlgili olarak uyumsuzluk maliyetleri ise yalnızca zamanlar aras1, tamamlanmamış bir sözleşme bağlamında ortaya çıkmaktadır. İşlem maliyeti teorisinin ayırt ediciliği olarak teşvikleri yeniden düzenlemek ve bunları fiyatlandırmak yerine, yönetim yapısının (piyasa, hiyerarşi veya hibrit) makul bir şekilde seçilmesi yoluyla bu maliyetleri azaltmak söz konusudur (Williamson, 1998: 572).

\subsection{Miyop Piyasa Teorisi}

Miyop kavramı adından da anlaşılacağı gibi hem tıp yazınında hem de Türk dil kurumu açıklamasında uzağı görememe durumu olarak ifade edilmektedir. İşletme yönetimi alanında da durum benzerdir. Çoğu zaman yatırımcıların görebildiği ya da görmeyi istedikleri kısa vadeli kazançları ifade etmektedir. Kısa vadede elde edilen kazançların başarısızlığa yol açabileceği olasıllğ 1 ile ortaya atılan bu teoriyi savunanlar şirket sorununa çözüm olarak yönetim kurulu ile hissedarlar arasında firma getirilerinin beklentisi durumunda aynı vadede olmaları bu sorunun çözümü olacaktır (Tufan, 2018: 12).

Şirket hissedarlarının yüksek gelir seviyesine ulaşması oldukça uzun dönemli bir bakış açısı gerektirmektedir. Ancak yöneticiler hemen sonuç alabilecekleri ve kendilerini gösterebilecekleri kısa vadeli miyop bakış açısına sahip kararlar alabilmektedirler. Miyop piyasa bakış açısı Anglo-Sakson kültürüne ait olduğu için ABD ve İngiltere gibi ülkelerde daha yaygın görülebilmektedir. Almanya ve Japonya gibi ülkelerde ise daha uzun soluklu yatırımların ve gelecek bakış açısının görülmesi yaygındır (Eldemir, 2019: 26).

\section{Kurumsal Yönetim İlkeleri}

Kurumsal yönetim herkes tarafından kabul gören dört temel ilkeye dayanmaktadır. Bu ilkeler; şeffaflık, adillik, sorumluluk ve hesap verilebilirliktir. Türkiye'de kurumsal yönetim ile ilgili yapılan düzenlemeler Sermaye Piyasası Kurulu (SPK) tarafindan oluşturulmaktadır. Bunun yanında farklı kurum ve kuruluşlar tarafından da çeşitli düzenlemeler yapılmaktadır (Gergin ve Şen 2019: 957). Bu dört ilkenin her birinin şirketlerin kurumsal yönetimi hakkında bilgi veren şirketin güvenirliliğine etki eden ilkeler olduğu ifade edilebilmektedir.

\subsection{Adillik İlkesi}

Adillik ilkesi, şirket yönetiminin bütün hak sahiplerine karşı adil şekilde davranma durumunu belirtmektedir. Bu ilkeye göre, bütün hak sahiplerinin azınlık hissedarları ve yabancı ortaklar da dahil olacak şekilde haklarının korunmasını güvence altına alınmasını ifade etmektedir. Adillik ilkesi, kurumsal yönetimin, hissedarlık haklarını koruyan ve bu hakların kullanılabilmesini kolaylaştıran bir çerçeve sunmalıdır. Hissedarların haklarının ihlal edilme durumunda ise tüm hissedarlar yeterli miktarda telafi veya tazminat elde etme hakkına sahip olmalılardır (Pamukçu, 2011: 135). Bu nedenle kurumsal yönetim şirketin tüm hissedarlarına hakların korunmasını sağlaması ve verdiği güvence nedeniyle kurumsal yönetimin önemini vurgulayan önemli ilkelerinden biridir. 


\section{2. Şeffaflık İlkesi}

Şeffaflık ilkesi sermaye piyasalarında finansal olarak istikrarın sağlanabilmesi açısından gerekli bir faktördür. Yaşanan küresel finansal krizlerde olduğu gibi şeffaflık uygulamalarındaki eksikliğin şirketin finansal istikrarını ve bütünlüğünü olumsuz yönde etkileyebildiği görülmektedir. Şeffaflık konusundaki uygulamalar ile beraber serbest piyasa mekanizması bilgi akışını firmalardan yatırımcılara etkili bir şekilde aktarmakta ve bu da disiplininin sağlanmasına imkân vermektedir. Şeffaflık ilkesi, belirsizlik durumlarında bilgi akışını sağlayarak piyasaların istikrarına katkı sağlamakta ve böylelikle politikaların etkinliğine katkı sağlamaktadır (Tekbaş ve Güzeldere, 2015: 4).

Şirketin finansal bilgilerinin ve paydaşlarının yatırımcıların bilmesi gereken önemli bilgilerin olabildiğince doğru ve eksiksiz bir şekilde gerçek bilgilerin paylaşılması önem arz etmektedir. Bu ilkenin şirketler tarafindan yerine getirilmesi neticesinde şirkete duyulan güvenin konusunda önem arz ettiği belirtilebilmektedir.

\subsection{Hesap Verebilirlik İlkesi}

Hesap verebilirlik ilkesi, yönetim kurulu üyelerinin pay sahiplerine ve anonim şirket tüzel kişiliğine olan hesap verme zorunluluğu belirtmektedir. Hesap verebilirlik ilkesi, şeffaflık ilkesinin aksine şirketlerin faaliyet sonrasını içermektedir (Pamukçu, 2011: 136). Şirketin faaliyetleri sonucunda şeffaf olarak bilgilendirme sağlayarak paydaşlarına, yatırımcılara karşı olan sorumluluklarını yerine getirmesini kapsamaktadır.

\subsection{Sorumluluk İlkesi}

Sorumluluk ilkesi, şirket yönetiminin tüm faaliyetlerinin toplumsal ve etik değerlere, mevzuata, esas sözleşmeye, şirket içi düzenlemelere göre uygunluğunu ve denetlenmesini açıklamaktadır. Böylelikle, kurumsal yönetim ile şirket ve hissedarlar arasında etkin ve mali yapının güçlendirilmesini sağlayabilecek bir işbirliğinin yapılabilmesi desteklenmelidir (Pamukçu, 2011: 135). Sorumluluk ilkesinde, şirketin tüm sorumluluklarını belirleyerek netleştirmesi ve bu doğrultuda faaliyetlerini gerçekleştirmesi gerekmektedir.

\section{Ekonomik İşbirliği ve Kalkınma Örgütü Kurumsal Yönetim (OECD) İlkeleri}

Uluslararası bazı büyük şirketlerin başına gelen skandallar, krizler sonucunda OECD kurumsal yönetim ilkelerini yayınlamış ve böylelikle dünyada ilkelere yönelik olarak bazı standartların oluşmasını sağlamıştır. Bilinçli yatırımcıların daha sistematik olarak yönetilen şirketlerin hisseleriyle daha çok ilgilenebildiği ifade edilebilmektedir. Bu sebeple şirketlerin kurumsal yönetimle yönetilip yönetilmemesi ve kurumsal yönetimin önemi söz konusudur (Kömeçoğlu ve Vuran, 2018: 705).

\section{SPK Kurumsal Yönetim İlkeleri}

Kurumsal yönetim mekanizmaları, politik süreçlere bağlı olarak değiştirilebilen yasal ve iktisadi kurumlardan oluşmaktadır. Türkiye'de SPK tarafindan ilkeler ilk olarak 2003 yılında yayımlanmıştır ve 2005 yılında güncellenmiştir. "Uygula, uygulamıyorsan açıkla" ilkesi ile hayata geçirilmiştir. SPK ilkelerinin yayımlanması öncesinde ve sonrasında kurumsal yönetim ilkelerinin uygulanabilmesi için uluslararası finansal raporlama standartlarının uygulanması, bağımsız denetim ve danışmanlık faaliyetlerinin ayrılması, halka arzlarda açıklamaların 
düzenlenmesi, özel durumların kamuya açıklanması, Kamuyu Aydınlatma Platformu'nun kurulması gibi birçok adım atılmıştır. Borsa İstanbul bünyesinde kurumsal yönetim endeksi oluşturulmuştur (Kavcar ve Gümrah, 2017: 104).

\section{Yazın Taraması}

Bu bölümde yurt içi ve yurt dışında 2000- 2021 yılları arasında kurumsal yönetim ile ilgili ele alınan makalelere ilişkin bir tarama gerçekleştirilmiştir. Bu amaçla, yurt içinde ulusal bir veritabanında yer alan, yurtdışında ise uluslararası bir veritabanlarında yer alan akademik dergilerdeki makaleler taranmıştır. Yurtdışı kapsamının çok geniş olması nedeniyle anahtar kelimelerle kısıtlanarak tarama gerçekleştirilmiştir. Çalışma kapsamında Şekil 1'de görüleceği üzere 2000-2021 yılları arasında akademik dergilerde yer alan çalışmaları kapsayan tarama sonucunda 117 Türkçe, 361 tane yabancı çalışma dahil edilmiştir.

Şekil 1 ve Şekil 2'de sırasıyla yurt içi ve dışında yayınlanan dergilerde yayınlanan makalelerin yıllara göre dağılımları görülmektedir. Yurt içinde gerçekleştirilen çalışma sayısının 2014 yılından itibaren artış trendi göstermeye devam ettiği söylenebilmektedir. Özellikle 2018 ve 2020 yıllarında kurumsal yönetim üzerine yapılmış çalışmaların diğer yıllara göre oldukça fazla olduğu görülmektedir.

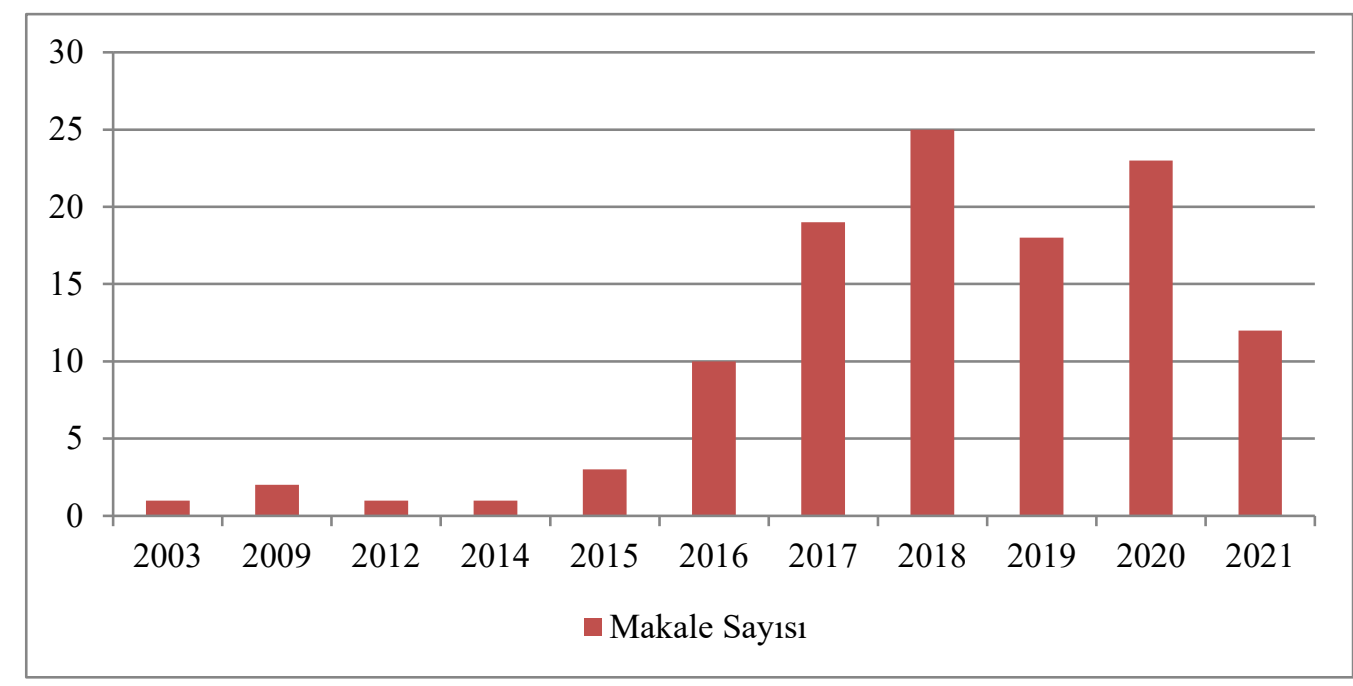

Şekil 1. Yurt İçindeki Dergilerde Yer Alan Makalelerin Yıllara Göre Dağılımı

Şekil 2 incelendiğinde yurt dışında gerçekleştirilen yayın sayılarının 2006 yılından itibaren artmaya başladığ 1 gösterdiği söylenebilmektedir. Özellikle 2011, 2014, 2017, 2019 ve 2020 yıllarında kurumsal yönetim üzerine çalışmalara diğer yıllara kıyasla fazla olduğunu söylemek mümkündür. 


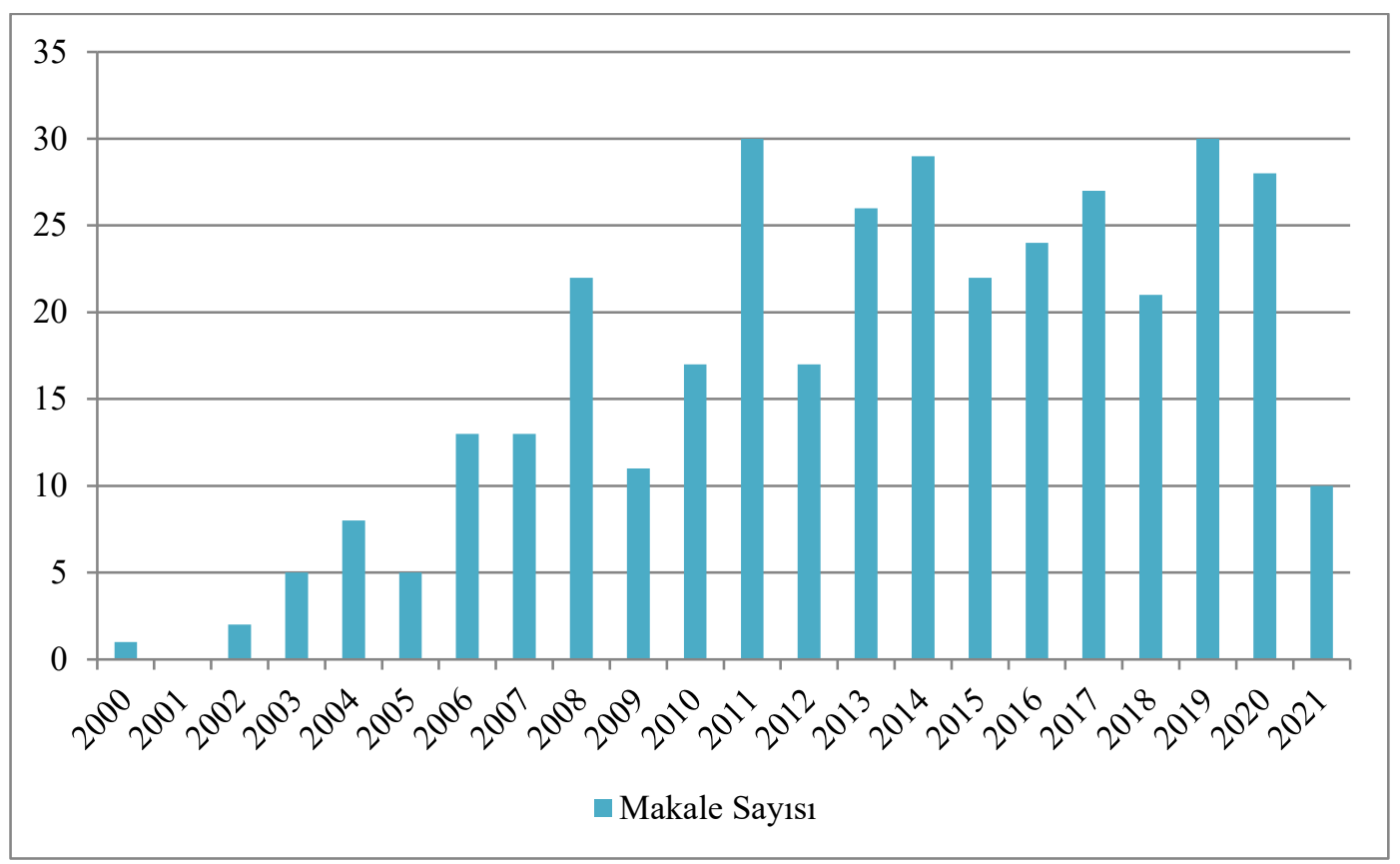

Şekil 2. Yurt Dışındaki Dergilerde Yer Alan Makalelerin Yıllara Göre Dağılımı

Ek 1'de Ulusal veritabanında Türkçe olarak yer alan makalelerde kurumsal yönetim konusu kapsamında ele alınan konuların anahtar kelimeleri yer almaktadır. Ek 1 incelendiğinde kurumsal yönetim endeksi, BIST, finansal performans, kurumsal yönetim ilkeleri, iç denetim, firma performansı, kurumsal sosyal sorumluluk gibi kavramların çoğunlukla ele alındığı söylenebilmektedir.

Uluslararası veri tabanında akademik dergilerde 2000-2021 yılları arasında yer alan dergiler "kurumsal yönetim (corporate governance)" ve "hisse senedi getirisi (stock return)" kelimelerine göre taranmıștır. Anahtar kelimelerle birlikte ele alınan kelimelere Ek 2'de yer verilmiştir. Ek 2 incelendiğinde çalışmalarda anahtar kavram olarak ele alınan konuların menkul kıymetler borsası, hisse senedi getiri oran1, menkul kıymetler ve ticaret borsaları, stok fiyatları, CEO'lar, hissedarlar, tüketici kredisi, sermayedarlar ve finansörler, finansal performans, yatırım bankacılığı ve menkul kıymet işlemleri, portföy yönetimi, birleşme ve devralmalar ve organizasyonel performans olduğu görülmektedir.

\section{Sonuç}

Kurumsal yönetim işletmelerin performansına, karlılığına etki eden, şirketlerin hedeflerine gerçekleştirmesine ve hedefleri ve sorumluluklarını netleştirmesine paydaşlarına ve yatırımcılar güven vermesine katkıda bulunarak işletmelerin devamlılığ s sağlamaktadır. Kurumsal yönetim, sadece işletmeler açısından fayda sağlamamakta aynı zamanda ülke ekonomisine de katkıda bulunan önemi yadsınamaz bir kavramdır. Bu nedenle kurumsal yönetim kavramı birçok kavramla birlikte ele alınarak yerli ve yabancı yazında oldukça fazla sayıda çalışmanın konusu oluşturmuştur.

$\mathrm{Bu}$ çalışmada kurumsal yönetim, kurumsal yönetim ile ilgili teoriler ve ilgili ilkeler hakkında bilgi verildikten sonra yerli ve yabancı yazında kurumsal yönetim üzerine yapılmış çalışmalara yönelik bir yazın taraması sunulmuştur. 2000 - 2021 yılları arasında akademik dergilerde yer alan çalışmaları kapsayan tarama sonucunda 117 Türkçe, 361 tane yabancı çalışma mevcut çalışmaya dahil edilmiştir. Çalışmaların önemli bir kısmı yurt dışında yapılmış olmakla birlikte, özellikle son üç yılda yurt içindeki yayınlanan çalışmalarda kurumsal 
yönetimin ele alan yayın sayısının artış gösterdiği gözlenmiştir. Yabancı yazında yapılan çalışmaların sayısı bazı yıllarda düşüş gösterse de son on yılda konunun daha fazla ele alındığı görülmektedir.

Araştırma sonucunda yerli yazında; kurumsal yönetim endeksi, BIST, finansal performans, kurumsal yönetim ilkeleri, iç denetim, firma performansı, kurumsal sosyal sorumluluk gibi anahtar kelimelerin ele alındığı görülürken yabancı yazında ise menkul kıymetler borsası, hisse senedi getiri oran1, menkul kıymetler ve ticaret borsaları, stok fiyatları, CEO'lar, hissedarlar, tüketici kredisi, sermayedarlar ve finansörler, finansal performans, yatırım bankacılığı ve menkul kıymet işlemleri, portföy yönetimi, birleşme ve devralmalar ve organizasyonel performans gibi anahtar kelimelerin daha çok ele alındığ 1 görülmüştür. $\mathrm{Bu}$ bilgilerden hareketle, finansal performans ve firma performansı konularının ortak olarak çoğunlukla ele alınan kavramlar olduğu görülmektedir. Yabancı yazında çoğunlukla yerli yazından farklı olarak birleşme ve devralmalar ve ticaret borsaları, stok fiyatları, yatırım bankacılığ 1 ve menkul kıymet işlemler gibi kavramların yer aldığı yorumu yapılabilmektedir.

Çalışmanın alan yazına kurumsal yönetim ile ilgili olarak yerli ve yabancı yazında yapılan çalışmaların konu ve çalışma sayısı eğiliminin ortaya koyulması açısından katkıda bulunduğu ifade edilebilmektedir. Ancak yerli yazında yapılan çalışmaların sadece bir ulusal veritabanında yayınlanan makalelerden, yabancı çalışmaların ise yine bir uluslararası veritabanında yayınlanan makalelerden seçilmesi çalışmanın kısıtını oluşturmaktadır. Ayrıca uluslararası veritabanında kurumsal yönetim ile ilgili çalışmaların oldukça fazla olması nedeniyle çalışmanın kapsamıyla ilgili olarak anahtar kelimelerle kısıtlanmıştır. Gelecek çalışmalarda sadece kurumsal yönetim kavramı ele alınarak tüm alanları kapsayacak şekilde birden fazla veritabanında çalışmalar ele alınarak eğilimin ortaya konulacağı çalışmaların ele alınması önerilebilmektedir. Böylelikle daha detaylı karşılaştırma yapmak mümkün olacaktır.

\section{Kaynakça}

Aghabaki, M. (2014). Kurumsal yönetim ilkeleri ile firma değeri ve hisse senedi getiri oranı arasındaki ilişkisi: IMKB'de bir uygulama. Doktora Tezi. Atatürk Üniversitesi Sosyal Bilimleri Enstitüsü. Erzurum.

Akın, D. A. (2004). Mülkiyet sahipliğinden kaynaklanan yönetim hakkının devri açısından post-modern yönetsel kontrol yaklaşımları ve stratejileri. Erciyes Üniversitesi İktisadi ve İdari Bilimler Fakültesi Dergisi, 0 (22). https://dergipark.org.tr/tr/pub/erciyesiibd.

Claessens, S. (2006). Corporate governance and development. The World Bank Research Observer, 2l(1), 91-122. https://doi.org/10.1093/wbro/lkj004.

Dincer, B. (2013). Kurumsal yönetimin farklı teoriler yoluyla değerlendirilmesi. Dumlupınar Üniversitesi Sosyal Bilimler Dergisi, 36,15-26. https://dergipark.org.tr/tr/pub/dpusbe.

Ekinci, B. (2017). Asil-Vekil arasındaki kayırmacılığın vekâlet maliyetleri ile ilişkisi. MANAS Sosyal Araştırmalar Dergisi,6(2), 73-96. https://dergipark.org.tr/tr/pub/mjss.

Eldemir, S. (2019). Kamu yönetiminde kurumsal yönetim ilkeleri ve bir kurumsal derecelendirme model önerisi. Hacettepe Üniversitesi Sosyal Bilimler Enstitüsü. Ankara.

Ertuğrul, F. (2008). Paydaş teorisi ve işletmelerin paydaşları ile ilişkilerinin yönetimi. Erciyes Üniversitesi Iktisadi ve İdari Bilimler Fakültesi Dergisi, O(31), 199-223. https://dergipark.org.tr/tr/pub/erciyesiibd.

Gergin, B. ve Şen, İ. K. (2019). Kurumsal yönetim endeksinde yer almanın bankaların performansına etkisi: Borsa İstanbul'da bir araştırma. Muhasebe Bilim Dünyası Dergisi, 21(4), 956-978. DOI: 10.31460/mbdd.562606.

Güvençer, Ü. C. (2008). Vekâlet teorisi: Firma performansına etkisi. (Yayınlanmamış Yüksek Lisans Tezi). Uludağ Üniversitesi Sosyal Bilimler Enstitüsü. Bursa. 
Karamustafa, O., Varıcı, İ. ve Er, B. (2009). Kurumsal yönetim ve firma performansı: İMKB kurumsal yönetim endeksi kapsamındaki firmalar üzerinde bir uygulama. Kocaeli Üniversitesi Sosyal Bilimler Enstitüsü Dergisi, 17(1), 100-119. https://dergipark.org.tr/tr/pub/kosbed.

Kavcar, B. ve Gümrah, Ü. (2017). Borsa İstanbul'da kurumsal yönetim ilkelerine uyum ve firma değeri: Olay çalışması. Ekonomik ve Sosyal Araştırmalar Dergisi, 13, 103-114. https://dergipark.org.tr/tr/pub/esad.

Khan, A., Muttakin, M. B. ve Siddiqui, J. (2013). Corporate governance and corporate social responsibility disclosures: Evidence from an emerging economy. J Bus Ethics, 114, 207223. https://doi.org/10.1007/s10551-012-1336-0.

Kömeçoğlu, E. ve Vuran, B. (2018). Kurumsal yönetim ile firma karlılığı arasındaki ilişki: Borsa İstanbul' da bir uygulama. Finans Ekonomi ve Sosyal Araştırmalar Dergisi, 3 (4), 704-713. DOI: $10.29106 /$ fesa.468383.

Mele, D. (2009). Corporate social responsibility theories, The Oxford Handbook of Corporate Social Responsibility, 47-82. DOI: 10.1093/oxfordhb/9780199211593.003.0003.

Mohamad, S. (2004). The importance of effective corporate governance. SSRN Electronic Journal, 1-10. http://dx.doi.org/10.2139/ssrn.617101.

Özsoy, Z. (2011). Kurumsal yönetim ve yönetim kurulları. İmge Kitabevi. Ankara.

Pamukçu, F. (2011). Finansal Raporlama ile kamuyu aydınlatma ve şeffaflıkta kurumsal yönetimin önemi. Muhasebe ve Finansman Dergisi, 133- 148. http://journal.mufad.org.tr/

Saldanl1, A. (2012). Kurumsal yönetim endeks performansının analizi. Ekonomik ve Sosyal Araştırmalar Dergisi, 8(8), 137-154.

Tekbaş, M. ve Güzeldere, H. (2015). The corporate governance and their effect on public companies. Journal of Economics Finance and Accounting, 2(1), 1- 17. https://dergipark.org.tr/tr/pub/jefa.

Tufan, H. (2018). Kurumsal yönetim ilkelerinin finansal performansa etkisi: Borsa İstanbul kurumsal yönetim endeksi'nde yer alan firmalar üzerine bir uygulama. Yüksek Lisans Tezi. Mersin üniversitesi Sosyal Bilimler Enstitüsü, Mersin.

Williamson, O. E. (1988). Corporate finance and corporate governance. The Journal of Finance, 43(3), 567-591. https://doi.org/10.2307/2328184.

Yavuz, S., Yıldırım, S. ve Elmas, B. (2015). Kurumsal yönetim endeksi ile şirket hisse senedi getiri ilişkisi: BIST'de bir uygulama. Erzincan Üniversitesi Sosyal Bilimler Enstitüsü Dergisi (ERZSOSDER), 8(2), 73-82. https://dergipark.org.tr/tr/pub/erzisosbil. 


\section{EKLER}

Ek 1. Türkçe Makalelerde Ele Alınan Anahtar Kavramlar

\begin{tabular}{|c|c|c|c|}
\hline Anahtar Kelime & Sayı & Anahtar Kelime & Sayı \\
\hline Kurumsal Yönetim Endeksi & 19 & Ulaşım Sektörü & 2 \\
\hline BIST & 15 & BIST 100 & 2 \\
\hline Finansal Performans & 13 & Derecelendirme Notu & 2 \\
\hline Kurumsal Yönetim İlkeleri & 10 & Kümülatif Anormal Getiri & 2 \\
\hline İç denetim & 8 & Entelektüel Sermaye & 2 \\
\hline Firma Performans1 & 8 & Muhasebe Meslek Mensupları & 2 \\
\hline Kurumsal sosyal sorumluluk & 7 & Kurumsal Yönetim Derecelendirme Notu & 2 \\
\hline BIST XKURY & 6 & Muhasebe Bilgi Sistemi & 2 \\
\hline Olay Çalışması & 6 & Kurumsal risk yönetimi & 2 \\
\hline Hisse senedi getirisi & 5 & Portföy & 1 \\
\hline Türkiye'de kurumsal Yönetim & 4 & Riskin Erken Saptanması Komitesi & 1 \\
\hline İç Kontrol & 4 & Karlılık & 1 \\
\hline KOBİ & 4 & Yönetim Kurulu & 1 \\
\hline TOPSİS Yöntemi & 3 & Şirketler & 1 \\
\hline Kurumsal Yönetim Notu & 3 & Sosyal Sorumluluk & 1 \\
\hline Kurumsal Yönetim Derecelendirmesi & 3 & Stepwise Çoklu Regresyon Analizi & 1 \\
\hline Sermaye Yap1s1 & 3 & Yönetimde Temsil & 1 \\
\hline Panel veri analizi & 3 & Endeks peformans1 & 1 \\
\hline Anonim Şirketler & 2 & Öz Sermaye Karlılı̆̆ 1 (ROE) & 1 \\
\hline Aile Şirketleri & 2 & Varlık Karlılığg (ROA) & 1 \\
\hline Denetim Komitesi & 2 & Sermaye Piyasaları & 1 \\
\hline Finansal Oranlar & 2 & Nitel araştırma & 1 \\
\hline Bağımsız Üyeler & 2 & Üniversite yönetimi & 1 \\
\hline Etik & 2 & Yükseköğretim & 1 \\
\hline Etik Kod & 2 & Lojistik Regresyon & 1 \\
\hline URF (Uyum Rapor Formatı) & 2 & ANOVA & 1 \\
\hline Firma Değeri & 2 & Kurumsallaşma & 1 \\
\hline Katılım bankacılığ1 & 2 & TMS & 1 \\
\hline Borsalar & 1 & TFRS & 1 \\
\hline Web Siteler & 1 & Performans & 1 \\
\hline Negatif Özgürlük & 1 & Uluslararası Denetim Standartlar1 & 1 \\
\hline Pozitif Özgürlük & 1 & Halka Açık Anonim Şirketler & 1 \\
\hline Kurumsal Yönetim İlkelerine Uyum Raporu & 1 & Sermaye Piyasaları & 1 \\
\hline İtibar & 1 & Menfaat Grupları & 1 \\
\hline Mezhebe Göre Eğitim. & 1 & Şeffaflık & 1 \\
\hline YK & 1 & Isaiah Berlin & 1 \\
\hline KYBF & 1 & Sürdürülebilirlik & 1 \\
\hline Kamu yönetimi & 1 & Pazarlama Stratejileri & 1 \\
\hline Pakistan & 1 & Covid-19 & 1 \\
\hline Medrese & 1 & Endekse Alınma & 1 \\
\hline Katılım Endeksi & 1 & Anormal Getiri & 1 \\
\hline Kurumsal yönetim algısı & 1 & Yönetim Kurulu & 1 \\
\hline Muhasebe Bilgi Kalitesi & 1 & Finansal Okuryazarlık & 1 \\
\hline Bağımsız Denetim & 1 & Şirket Performans1 & 1 \\
\hline Çok Kriterli Karar Yöntemleri & 1 & COVID-19 Pandemisi & 1 \\
\hline BIST Banka Endeksi & 1 & Gri İlişkisel Analiz Metodu & 1 \\
\hline Türkiye'de Kurumsal Yönetimin Gelişimi & 1 & MAUT Metodu & 1 \\
\hline Sermaye Piyasası Kurulu & 1 & Finansal Başarısızlık & 1 \\
\hline OECD & 1 & Lojistik Regresyon & 1 \\
\hline Firma Karlılı̆̆1 & 1 & Faaliyet Raporları & 1 \\
\hline Panel Regresyon & 1 & Endeks Performans1 & 1 \\
\hline Kamuyu Aydınlatma İlkesi & 1 & Vekalet Maliyeti & 1 \\
\hline Yönetişim & 1 & ISO 500 Firmaları & 1 \\
\hline
\end{tabular}


Ek 1 (Devamı). Türkçe Makalelerde Ele Alınan Anahtar Kavramlar

\begin{tabular}{|c|c|c|c|}
\hline Kurumsal öğrenme & 1 & 2001 Finansal Krizi & 1 \\
\hline Bilgi Yönetimi & 1 & Basel II & 1 \\
\hline Entegre Raporlama & 1 & Derecelendirme & 1 \\
\hline Entegre Rapor & 1 & Muhasebe Mesleği & 1 \\
\hline Kurumsal Yönetişim & 1 & Risk & 1 \\
\hline Uluslararası Finansal Raporlama Standartları & 1 & Çok Kriterli Karar Verme Yöntemleri & 1 \\
\hline Mülkiyet Açıklama Kuralları & 1 & Genel Kurul & 1 \\
\hline Pay Sahipliği & 1 & Pay Sahipleri Demokrasisi & 1 \\
\hline Merkezi Kayıt Kuruluşu & 1 & Çoğunluk Pay Sahipleri & 1 \\
\hline Yönetim Kurulu Yapısı & 1 & Azınlık Pay Sahipleri & 1 \\
\hline İhtiyatll1ık & 1 & Korku Endeksi (VIX) & 1 \\
\hline Değer Yaratma & 1 & ARDL Modeli & 1 \\
\hline Kaynak temelli görüş & 1 & Sinır Testi & 1 \\
\hline Çalışan ilişkileri & 1 & Cam Tavan & 1 \\
\hline Çıkar Çatışması & 1 & Bağımsız denetçi & 1 \\
\hline Kurumsal Raporlama & 1 & Sürdürülebilirlik Endeksi & 1 \\
\hline Finansal Başarı & 1 & Entegre Raporlama & 1 \\
\hline Kazak Bankacılık sistemi & 1 & Entelektüel Katma Değer Katsayısı & 1 \\
\hline Finansal Kaldıraç & 1 & BİST Kurumsal Yönetim Endeksi & 1 \\
\hline Vizyon & 1 & Sistem GMM & 1 \\
\hline İslami finans & 1 & Misyon & 1 \\
\hline Danışma kurulları & 1 & Etik Değerler & 1 \\
\hline Söylem & 1 & Korelasyon Analizi & 1 \\
\hline Retorik & 1 & Borsa İstanbul Şirketleri & 1 \\
\hline Yönetim Uygulamasının İnşası & 1 & İmalat Sanayi & 1 \\
\hline İhtiyatlı Muhasebe & 1 & Kamu İktisadi Teşebbüsü & 1 \\
\hline Ortak kontrol & 1 & $\mathrm{ARCH}$ & 1 \\
\hline Şirket birleşmesi & 1 & GARCH & 1 \\
\hline Hakların birleştirilmesi & 1 & Volatilite & 1 \\
\hline Elektronik Genel Kurul & 1 & SWARCH & 1 \\
\hline Pay Sahipliği Hakları & 1 & Kazanç Yönetimi & 1 \\
\hline İşletme Yönetimi & 1 & Kazanç Yönetimi Motivasyonları & 1 \\
\hline Organizasyon & 1 & Oran analizi & 1 \\
\hline Piyasa Performans1 & 1 & Yeni raporlama düzeni & 1 \\
\hline Kurumsal Yönetim Uygulamaları & 1 & Bankalar & 1 \\
\hline Yeni Türk Ticaret Kanunu & 1 & Kurumsal Sosyal Sorumluluk Raporlaması & 1 \\
\hline İç Denetim Standartları & 1 & Sürdürülebilirlik Raporlaması & 1 \\
\hline Kurumsal Yönetim Kalitesi & 1 & Gönüllü Raporlama & 1 \\
\hline Portföy Optimizasyonu & 1 & Kar Payı Politikası & 1 \\
\hline Optimum Portföy & 1 & Özsermaye Karlılı̆̆ 1 & 1 \\
\hline Ortalama Varyans Modeli & 1 & Muhafazakarlık & 1 \\
\hline Halkla İlişkiler & 1 & Kurumsal Yönetim & 1 \\
\hline Bankacılık & 1 & Denetim Kalitesi & 1 \\
\hline Finans & 1 & Aktif Karlılı̆̆1 & 1 \\
\hline Sigorta şirketleri & 1 & Getiri & 1 \\
\hline Havuzlandırılmış Regresyon Model & 1 & Nükleer Enerji Maliyetleri & 1 \\
\hline BIST Sürdürülebilirlik Endeksi & 1 & Depolama ve Devre Dışı Bırakma Maliyeti & 1 \\
\hline İçerik Analizi & 1 & Nükleer Enerji Şirketinin Finansal Tablolar & 1 \\
\hline Dinamik Panel Veri Analiz & 1 & Türk Kurumsal Yönetim Yapısı & 1 \\
\hline
\end{tabular}


Ek 2. Yabancı Makalelerde Ele Alınan Anahtar Kavramlar

\begin{tabular}{|c|c|c|c|}
\hline Anahtar Kelime & Sayı & Anahtar Kelime & Sayı \\
\hline Menkul Kıymetler Borsası & 68 & Güvenlik Sistemleri Hizmetleri & 1 \\
\hline Hisse Senedi Getiri Oranı & 67 & Kitle İletişim Araçları ve iş & 1 \\
\hline Menkul Kiymetler ve Ticaret Borsaları & 64 & Yatırım Yapmama & 1 \\
\hline Getiri oran1 & 49 & İş İletişimi & 1 \\
\hline Hisse Senetleri (Finans) & 45 & Gizli Görüşmeler & 1 \\
\hline Stok fiyatları & 44 & Finansal Piyasalar & 1 \\
\hline CEO'lar & 43 & Önleme & 1 \\
\hline Hissedarlar & 39 & İskandinavya & 1 \\
\hline Tüketici Kredisi & 31 & Faiz oran1 Riski & 1 \\
\hline Sermayedarlar ve finansörler & 30 & Finans Şirketleri & 1 \\
\hline Finansal performans & 29 & Blok Ticareti & 1 \\
\hline Yatırım Bankacılığı ve Menkul Kıymet İşlemleri & 28 & $\begin{array}{l}\text { Fizik Mühendisliği ve Yaşam Bilimlerinde Araştırma } \\
\text { ve Geliştirme }\end{array}$ & 1 \\
\hline Portföy Yönetimi & 28 & Bölgesel bankalar & 1 \\
\hline Çin & 25 & Değerleme Bağımsız Yazarlar & 1 \\
\hline Birleşme ve Devralmalar & 25 & Bağımsız Sanatçılar & 1 \\
\hline Yatırım Tavsiyesi & 23 & Yazarlar ve Oyuncular & 1 \\
\hline Finansal Krizler & 23 & Konsensüs (Sosyal bilimler) & 1 \\
\hline Organizasyonel Performans & 23 & Anketler & 1 \\
\hline Yönetici Tazminatı & 23 & Yazarlar & 1 \\
\hline İşletmeler & 22 & Kurumsal Borç & 1 \\
\hline Yatırımlar & 22 & Maden Endüstrileri & 1 \\
\hline Çeşitli Finansal Yatırım Faaliyetleri & 22 & Vadeli İşlemler & 1 \\
\hline Kurumsal Finansman & 22 & Maden, Cevher ve Değerli Metal Tüccarı Toptancıları & 1 \\
\hline Endüstriyel Yönetim & 21 & Kömür ve Diğer Maden ve Cevher Toptancıları & 1 \\
\hline Piyasa Oynaklığı & 18 & Kurumsal Geri Dönüşler & 1 \\
\hline İşgücü Teşvikleri & 17 & Tahviller (Finans) & 1 \\
\hline Kurumsal Yöneticiler & 17 & Kuveyt & 1 \\
\hline Amerika Birleşik Devletleri & 16 & Denetim Ücretleri & 1 \\
\hline Yönetim Kurulları & 16 & Almanya & 1 \\
\hline Hissedar zenginliği & 15 & Finansal Planlama & 1 \\
\hline Bankacılık sektörü & 15 & Mavi çip stokları & 1 \\
\hline Tasarruf Kurumları & 15 & Gelişmiş ülkeler & 1 \\
\hline Ticari Bankacılık & 15 & Kısa vadeli işletme finansmanı & 1 \\
\hline Sermaye Piyasası & 15 & Geçiș ekonomileri & 1 \\
\hline Stok fiyatları & 14 & Merkezi ekonomik planlama & 1 \\
\hline İşletmenin sosyal sorumluluğu & 13 & Tecrübeli hisse teklifleri & 1 \\
\hline Halka açılma (Menkul Kıymetler) & 12 & Stok geri alımı & 1 \\
\hline Kişisel ve ticari bankacılık sektörü & 12 & Çalışan yorumları & 1 \\
\hline Vekalet Teorisi & 11 & Özel şirketler & 1 \\
\hline Finansal Risk & 11 & Büyük şirketler & 1 \\
\hline Regresyon Analizi & 11 & Para arz1 & 1 \\
\hline Diğer Mevduat Kredisi Aracılığ & 10 & Kurumsal Bankacılık & 1 \\
\hline Stok Geri Alımı & 10 & Tayland & 1 \\
\hline Mali Tablolar & 10 & Bankacılık Sektörü & 1 \\
\hline Kurumsal Yatırımcilar & 10 & Ekonomik Eğilimler & 1 \\
\hline Ekonomik Rekabet & 9 & Kore & 1 \\
\hline Likidite (Ekonomi) & 9 & Firmanın işlem maliyeti teorisi & 1 \\
\hline Merkezi kredi birlikleri & 9 & Bilgi Ekonomisi & 1 \\
\hline Açık Uçlu Yatırım Fonları & 8 & Parasal Teşvikler & 1 \\
\hline Şirket Karları & 8 & Endüstriyel Üretkenlik & 1 \\
\hline Hisse senedi Sahipliği & 8 & Japonya & 1 \\
\hline Menkul Kiymetler Aracılığ1 & 8 & Belçika & 1 \\
\hline Finans & 8 & Yatırım Bütçesi & 1 \\
\hline Şirketlerin Değerlemesi & 8 & Japon İnsanlar & 1 \\
\hline Hissedar Aktivizmi & 8 & Bireycilik & 1 \\
\hline
\end{tabular}


Ek 2 (Devam). Yabancı Makalelerde Ele Alınan Anahtar Kavramlar

\begin{tabular}{|c|c|c|c|}
\hline Finansal Kaldıraç & 8 & İş Geliri & 1 \\
\hline $\begin{array}{l}\text { Finansal İşlemlerin İşlenmesi, Rezerv ve Takas } \\
\text { Merkezi Faaliyetleri }\end{array}$ & 8 & Finansal analistler & 1 \\
\hline Açıklama & 7 & Dağılım & 1 \\
\hline Ekonomik Gelişme & 7 & Stok transferi & 1 \\
\hline Karar Verme & 7 & Sanayileşme & 1 \\
\hline Muhasebe & 7 & Genel Ekonomik Programların Yönetimi & 1 \\
\hline Karlıl1k & 7 & Ekonomik sektörler & 1 \\
\hline Varlık Getirisi & 7 & Şirketler ve etik & 1 \\
\hline Yatırımcı İlişkileri (Kurumlar) & 7 & Piyasa fiyatlandırması & 1 \\
\hline Anormal Getiriler & 7 & Para piyasas1 & 1 \\
\hline Nakit akımı & 7 & Finansal ekonomi & 1 \\
\hline İş cirosu & 7 & Skandallar & 1 \\
\hline Gelişmekte Olan Piyasalar & 6 & Ödeme & 1 \\
\hline Performans & 6 & Ofis kuralları & 1 \\
\hline Paydaşlar & 6 & Bağ 1 lşar & 1 \\
\hline Performans değerlendirmesi & 6 & Hibe Kuruluşları & 1 \\
\hline Ekonomik Etki & 6 & Durgunluk (Ekonomi) & 1 \\
\hline Temettüler & 6 & Baş risk görevlileri & 1 \\
\hline Finansal Piyasalar & 6 & Proxy erişimi (Hissedarlar) & 1 \\
\hline Finansal piyasa tepkisi & 6 & Proxy danışmanları & 1 \\
\hline Sermaye yatırımları & 6 & Hissedarların oyları & 1 \\
\hline Ampirik araştırma & 6 & Bilgi ve iletişim teknolojileri & 1 \\
\hline Yöneticiler & 6 & Elektronik Ticaret & 1 \\
\hline Yönetmek & 6 & $\begin{array}{l}\text { İnternet Yayıncılı̆̆ } 1 \text { ve Yayıncılığı ve Web Arama } \\
\text { Portalları }\end{array}$ & 1 \\
\hline Kazanç Yönetimi & 5 & Kablolu Telekomünikasyon Taşıyıcıları & 1 \\
\hline Hissedarların rüçhan hakları & 5 & Elektronik Alışveriş & 1 \\
\hline Brezilya & 5 & Elektronik alışveriş ve posta siparişi evleri & 1 \\
\hline İş hayatında risk yönetimi & 5 & Dijital medya & 1 \\
\hline Avustralya & 5 & Mülk & 1 \\
\hline Eşitlik & 5 & İşadamları & 1 \\
\hline Denetim komiteleri & 5 & Finansal İşlemlerin İşlenmesi & 1 \\
\hline Halka açık şirketler & 5 & Rezerv ve Takas Merkezi Faaliyetleri & 1 \\
\hline Ekonomi & 5 & Menkul Kıymetler Düzenleme Komisyonu & 1 \\
\hline Bilgi asimetrisi & 5 & Cumhurbaşkanlığı seçimleri & 1 \\
\hline Kurumsal reform & 5 & Oy verme yerleri & 1 \\
\hline Hedge fonlar & 5 & İşten çıkarma tazminatı & 1 \\
\hline Menkul Kiymetler ve Borsa Komisyonu & 5 & Kötü haber & 1 \\
\hline $\begin{array}{l}\text { Muhtelif Ticari Sektörlerin Düzenlenmesi, } \\
\text { Ruhsatlandırılması ve Denetimi }\end{array}$ & 5 & Vekil & 1 \\
\hline Hindistan & 4 & Derecelendirmeler ve Siralamalar & 1 \\
\hline Diğer tüm mevduat dış1 kredi aracılığ1 & 4 & Risk Alg1lamas1 & 1 \\
\hline Diğer Finansal Araçlar & 4 & Yedekleme planlaması & 1 \\
\hline Vekil talebi & 4 & Yönetici veraset & 1 \\
\hline Varlıklar (Muhasebe) & 4 & Yönetim cirosu & 1 \\
\hline Büyük Britanya & 4 & Sosyal ağlar & 1 \\
\hline Kurumsal Mülkiyet & 4 & İş dünyasında trend analizi & 1 \\
\hline Ücretler & 4 & Soruşturmalar & 1 \\
\hline Matematiksel modeller & 4 & Özel olarak yerleştirilmiş menkul kıymetler & 1 \\
\hline Şirket raporları & 4 & Uluslararası ticari işletmeler & 1 \\
\hline Hisse senedi seçenekleri & 4 & Değerleme & 1 \\
\hline İş değeri & 4 & Sera gazları & 1 \\
\hline Menkul kıymetlerde içeriden öğrenenlerin ticareti & 4 & Emisyonlar (Hava kirliliği) & 1 \\
\hline Finansal açıklama & 4 & Fiyat fark1 & 1 \\
\hline Hissedarlar toplantıları & 4 & Küçük iş & 1 \\
\hline Kurumsal yatırımlar & 4 & Uluslararas1 Pazarlar & 1 \\
\hline
\end{tabular}


Ek 2 (Devam). Yabancı Makalelerde Ele Alınan Anahtar Kavramlar

\begin{tabular}{|c|c|c|c|}
\hline Kurumsal büyüme & 4 & Şirketlerin Kadın Yöneticileri & 1 \\
\hline Araştırma \& Geliştirme & 4 & Aile İlişkileri & 1 \\
\hline Biyoteknolojide Araştırma ve Geliştirme & 4 & Muhafazakarlık (Muhasebe) & 1 \\
\hline Risk alma davranışı & 4 & Mali Y1l & 1 \\
\hline Proxy ifadeleri & 4 & İş performans1 & 1 \\
\hline Finansal Kurumlar & 4 & Tazminat yönetimi & 1 \\
\hline Etik yatırımlar & 4 & İnsan Kaynakları Danışmanlık Hizmetleri & 1 \\
\hline Halka açılma (Menkul Kıymetler) & 4 & Makul değer & 1 \\
\hline Küresel Finansal Kriz & 4 & Yolsuzluk & 1 \\
\hline Şirket hukuku & 4 & Çatışma yönetimi & 1 \\
\hline Aile şirketlerine ait işletmeler & 4 & Makroekonomi & 1 \\
\hline Kurumsal Perde & 4 & Servet etkisi (Ekonomi) & 1 \\
\hline Etkin piyasa teorisi & 3 & Çalışan sahipliği & 1 \\
\hline Sermaye varlıkları fiyatlandırma modeli & 3 & Veri analizi & 1 \\
\hline İş Tahmini & 3 & Ortak girişimler & 1 \\
\hline Denetim komiteleri & 3 & Kurumsal İletişim & 1 \\
\hline Yatırım politikası & 3 & Açık Piyasa İşlemleri & 1 \\
\hline $\begin{array}{l}\text { Sosyal ve Beşeri Bilimlerde Araştırma ve } \\
\text { Geliştirme }\end{array}$ & 3 & Kampanya Fonları & 1 \\
\hline Şirketler & 3 & Kazanç Yönetimi & 1 \\
\hline Menkul kıymetler & 3 & Finans kurumlarının düzenlenmesi & 1 \\
\hline Diğer Bireysel ve Aile Hizmetleri & 3 & Serbest nakit akışı & 1 \\
\hline Değerleme & 3 & Siyasi Örgütler & 1 \\
\hline Finansal hizmetler sektörü & 3 & Siyasi adaylar & 1 \\
\hline Temettü politikası & 3 & Sorumluluk sigortas1 & 1 \\
\hline Yatırımc1 korumas1 & 3 & Yatırım analizi & 1 \\
\hline Personel Yönetimi & 3 & Matematiksel seçenek modelleri & 1 \\
\hline İnsan Kaynakları Danışmanlık Hizmetleri & 3 & İş hayatında karar verme & 1 \\
\hline Kurumsal yeniden yapılanmalar & 3 & Finans Politikası & 1 \\
\hline İş planlaması & 3 & Riskten Kaçınma & 1 \\
\hline Mülk & 3 & Küreselleşme & 1 \\
\hline Başkent & 3 & Yabancı Yatırımlar & 1 \\
\hline En Küçük Kareler & 3 & Beklenen Getiriler & 1 \\
\hline Özel Sektör & 3 & Seçenekler (Finans) & 1 \\
\hline Kazanç Tahmini & 3 & Matematiksel Finans Modelleri & 1 \\
\hline Bilgi Paylaşımı & 3 & Yanıltıcı Mali Tablolar & 1 \\
\hline Liderlik & 3 & Sigorta Primleri & 1 \\
\hline Girişim Sermayesi & 3 & Doğrudan Sorumluluk Sigortası Taşıyıcıları & 1 \\
\hline Menkul Kiymet Ticareti & 3 & Çalışan İkramiyeleri & 1 \\
\hline Ekonomik Koşullar & 3 & Sözleşmeler & 1 \\
\hline Kurumsal Finans Yönetimi & 3 & Menkul Kiymet Fiyatları & 1 \\
\hline Uzun Dönem (Ekonomi) & 3 & İhbar & 1 \\
\hline Güvenilir Emeklilik Fonları & 3 & Politika Bilimi & 1 \\
\hline Yürütme Yeteneği (Yönetim) & 3 & Kurumsal Kazancın Yeniden Beyanı & 1 \\
\hline Ekonomide bilgi teorisi & 3 & Muhasebede Yolsuzluk uygulamaları & 1 \\
\hline Kredi derecelendirme & 3 & Muhasebe Hilesi & 1 \\
\hline Market değeri & 3 & İhbarcilar & 1 \\
\hline Finansal Yönetim & 3 & Devlet mülkiyeti & 1 \\
\hline Muhasebe Standartları & 3 & Menkul kıymetlerin listelenmesi & 1 \\
\hline Kesit yöntemi & 3 & Motivasyon & 1 \\
\hline Risk değerlendirmesi & 3 & İş tahmini & 1 \\
\hline Olasılık teorisi & 3 & Büyüme oranı & 1 \\
\hline Kamu görevlileri & 3 & Gayri Safi Milli Hasıla & 1 \\
\hline Gelişmekte olan ülkeler & 3 & Yatırım Riski & 1 \\
\hline Özelleşmek (Menkul Kıymetler) & 3 & Bilgi Depolama ve Alma Sistemleri & 1 \\
\hline Yatırım Fonları & 3 & Vergilendirme & 1 \\
\hline Ekonomik Göstergeler & 2 & Yönetim Kontrolleri & 1 \\
\hline
\end{tabular}


Ek 2 (Devam). Yabancı Makalelerde Ele Alınan Anahtar Kavramlar

\begin{tabular}{|c|c|c|c|}
\hline Diğer tüm Finansal Yatırım Faaliyetleri & 2 & Aile şirketleri & 1 \\
\hline Örgütsel İdeoloji & 2 & Kefaret (Hukuk) & 1 \\
\hline GARCH modeli & 2 & Çalışan kuralları & 1 \\
\hline Fiyat & 2 & Oynaklık (Menkul Kıymetler) & 1 \\
\hline İstanbul Menkul Kıymetler Borsası & 2 & Sigorta Acenteleri ve Aracı Kurumlar & 1 \\
\hline Asya & 2 & Belirsizlik & 1 \\
\hline Kazanç duyuruları & 2 & Ekonomik politika & 1 \\
\hline Kurumsal elden çıkarma & 2 & Ekonomik genişleme & 1 \\
\hline Petrol ve Petrol Ürünleri Toptancıları & 2 & Kendi kendini organize eden haritalar & 1 \\
\hline İstanbul, Türkiye & 2 & Küme analizi & 1 \\
\hline Anormal Getiriler & 2 & Performans standartları & 1 \\
\hline Panel Analizi & 2 & Performans Yönetimi & 1 \\
\hline Stratejik Planlama & 2 & $\begin{array}{l}\text { İdari Yönetim ve Genel Yönetim Danışmanlığ } 1 \\
\text { Hizmetleri }\end{array}$ & 1 \\
\hline Anormal Getiriler & 2 & Net varlık değeri & 1 \\
\hline Avrupa & 2 & Ekonomik aktivite & 1 \\
\hline Yeni Zelanda & 2 & Demokratlar & 1 \\
\hline Denetim & 2 & Kuralsızlaştırma & 1 \\
\hline Ampirik araştırma & 2 & Denetçi değişiklikleri & 1 \\
\hline Kanit & 2 & Denetçi raporları & 1 \\
\hline Kendine özgü risk (Menkul kıymetler) & 2 & Kalite kontrol & 1 \\
\hline Kuruluşlarda şeffaflık & 2 & İş ahlak1 & 1 \\
\hline Sahtekâr & 2 & Hisse senedi için hisse senedi işlemleri & 1 \\
\hline Hukuk ve mevzuat & 2 & Makul değer & 1 \\
\hline Iş gücü dönüşümü & 2 & İslami finans & 1 \\
\hline Azınlık hissedarları & 2 & Finanstaki beklenmedik durumlar & 1 \\
\hline Kuruluş değeri & 2 & Tahmin modelleri & 1 \\
\hline Sosyal etki & 2 & Nedensel modeller & 1 \\
\hline Banka yönetimi & 2 & Kalite güvencesi & 1 \\
\hline Gelişmiş ülkeler & 2 & Belediye şirketleri & 1 \\
\hline Muhasebe yöntemleri & 2 & Sertifika & 1 \\
\hline Temel bileşenler Analizi & 2 & Kalite kontrol standartları & 1 \\
\hline Ekonometri & 2 & ISO 9000 Serisi Standartları & 1 \\
\hline Diğer Gayrimenkul Mülklerini Kiraya Verenler & 2 & Kaza sigortas1 & 1 \\
\hline İçsellik (Ekonometri) & 2 & Satışlardan elde edilen getiriler & 1 \\
\hline Faizciler & 2 & Diyagramlar & 1 \\
\hline Şirketlerin dış yöneticileri & 2 & Standart sapmalar & 1 \\
\hline Menkul kıymetlerin çapraz listelenmesi & 2 & Avrupa Birliği ülkeleri & 1 \\
\hline Endüstriyel verimlilik & 2 & Endüstriler ve toplum & 1 \\
\hline İşgücü verimliliği & 2 & İş şartları & 1 \\
\hline Ajans maliyetleri & 2 & Restoranlar & 1 \\
\hline İşlem maliyetleri & 2 & Zararlar & 1 \\
\hline Sermaye maliyetleri & 2 & Hükümet düzenlemeleri & 1 \\
\hline Ekonomik reform & 2 & Sigorta şirketleri & 1 \\
\hline Yapısal uyum (Ekonomi politikası) & 2 & Sigorta rezervleri & 1 \\
\hline Rusya & 2 & Korelasyon (İstatistikler) & 1 \\
\hline İşletme boyutu & 2 & Düzenlenmiş endüstriler & 1 \\
\hline Değer yaratma & 2 & New York Borsas1 & 1 \\
\hline Japon şirketleri & 2 & NASDAQ Borsası & 1 \\
\hline Riske maruz kalma & 2 & İşyerinde çeşitlilik & 1 \\
\hline Japonya & 2 & İş sosyolojisi & 1 \\
\hline Hukuk reformu & 2 & Mesleki başarının tahmini & 1 \\
\hline Banka hisseleri & 2 & İş dünyasında yaratıcı yetenek & 1 \\
\hline Vietnam & 2 & Kritik başarı faktörü & 1 \\
\hline Emeklilik & 2 & İş zekası & 1 \\
\hline İş finansı & 2 & Üretim standartları & 1 \\
\hline Kıyaslama (Yönetim) & 2 & Kadın yöneticiler & 1 \\
\hline
\end{tabular}


Ek 2 (Devam). Yabancı Makalelerde Ele Alınan Anahtar Kavramlar

\begin{tabular}{|c|c|c|c|}
\hline Kredi Büroları & 2 & Reformlar & 1 \\
\hline Hükümet politikası & 2 & Ekonomik özgürlük & 1 \\
\hline Ekonomik istikrar & 2 & Avrupa Birliği & 1 \\
\hline Piyasa kapitalizasyonu & 2 & Kurumsal çevre & 1 \\
\hline Ticari işletmeler ve çevre & 2 & Uluslararas1 finans & 1 \\
\hline Kurumsal derecelendirme & 2 & Retrospektif çalışmalar & 1 \\
\hline Endonezya & 2 & Yatırım danışmanları & 1 \\
\hline Devlet işletmeleri & 2 & Veritabanları & 1 \\
\hline Çarpıklık(Olasılık teorisi) & 2 & Tanımlayıcı istatistikler & 1 \\
\hline Ekonomik karar verme & 2 & Kar maksimizasyonu & 1 \\
\hline Piyasalar & 2 & Market fiyatları & 1 \\
\hline Ticaret & 2 & Kredi temerrüt takasları & 1 \\
\hline Cinsiyet & 2 & Ekonomik araştırma & 1 \\
\hline Yeminli Mali Müşavirlik Büroları & 2 & Risk primleri & 1 \\
\hline Muhasebeci büroları & 2 & EBITDA (Accounting) & 1 \\
\hline Muhasebe firmaları & 2 & Yönetim bilimi araştırması & 1 \\
\hline Üst düzey yöneticilerin yasal statüsü & 2 & Örgütsel davranış araştırması & 1 \\
\hline Ticaret hukuku & 2 & Doğrudan genel mal ve kaza sigortası taşıyıcıları & 1 \\
\hline Açı̆̆a satış (Menkul Kıymetler) & 2 & Sermaye yönetimi & 1 \\
\hline Piyasa zamanlaması & 2 & Altın paraşütler & 1 \\
\hline İş ve siyaset & 2 & Çift sınıf hisse senetleri & 1 \\
\hline Uluslararası Ticaret Finansmanı & 2 & Görev süresi & 1 \\
\hline Doğrudan Mülkiyet ve Kaza Sigortası Taşıyıcıları & 2 & Cinsiyet farklılıkları & 1 \\
\hline Performans için ödeme yapın & 2 & Cinsiyet eşitsizliği & 1 \\
\hline Finlandiya & 2 & Genelleştirilmiş moment yöntemi & 1 \\
\hline İş büyümesi & 2 & Kadın çalışanlar & 1 \\
\hline Hisse senedi fiyat endeksleri & 2 & Emeklilik tröstleri & 1 \\
\hline Devralma önleme stratejileri & 2 & Eşzamanlı denklemler & 1 \\
\hline İsveç & 2 & Çeşitli Aracılık & 1 \\
\hline Varlık satışları ve fiyatları & 2 & Garantili yatırım sözleşmeleri & 1 \\
\hline İnsan Kaynakları Programlarının Yönetimi & 2 & Sosyal Güvenlik & 1 \\
\hline Kurumsal kazançların yeniden beyanı & 2 & Kurumsal elden çıarma & 1 \\
\hline Sosyal sorumluluk & 2 & Finansal Kurumlar & 1 \\
\hline Doğrudan Sağlık ve Sağlık Sigortası Taşıyıcıları & 2 & Güvenilmeyen emeklilik fonları & 1 \\
\hline XBRL (Belge biçimlendirme dili) & 2 & Emeklilik fonları & 1 \\
\hline İş başarısı & 2 & Bireysel yatırımcılar & 1 \\
\hline Şirket kültürü & 2 & Momentler yöntemi (İstatistikler) & 1 \\
\hline Ölçek ekonomileri & 2 & Fransa & 1 \\
\hline Örgütsel sosyoloji & 2 & Döviz piyasas1 & 1 \\
\hline Nakit yönetimi & 2 & Tecrübeli hisse teklifleri & 1 \\
\hline Finansal araştırma & 2 & Sosyal sermaye & 1 \\
\hline Fiyatlandırma & 2 & İç denetim & 1 \\
\hline Kredi Aracılığına İlişkin Diğer Faaliyetler & 2 & Kredi & 1 \\
\hline $\begin{array}{l}\text { Fizik, Mühendislik ve Yaşam Bilimlerinde } \\
\text { Araştırma ve Geliştirme }\end{array}$ & 2 & Girişim sermayesi şirketleri & 1 \\
\hline Sosyal savunuculuk kuruluşları & 2 & Siyasi katılım & 1 \\
\hline Tutumlar & 2 & Hava kirliliği & 1 \\
\hline Ürün iadeleri & 1 & Özelleştirme & 1 \\
\hline Güvenlik sistemi & 1 & Geri alım anlaşmaları & 1 \\
\hline Yaşam döngüsü maliyetlemesi & 1 & Ekonomik modeller & 1 \\
\hline Ücret artışları & 1 & Kullanılan sermayenin getirisi & 1 \\
\hline İşçilik maliyetleri & 1 & $\begin{array}{l}\text { Kentsel Planlama ve Toplum ve Kırsal Kalkınma } \\
\text { İdaresi }\end{array}$ & 1 \\
\hline Temel performans göstergeleri (Yönetim) & 1 & Duyarl111k analizi & 1 \\
\hline Bilgi kaynakları & 1 & Kukla değişkenler & 1 \\
\hline Uyumlulaştırma & 1 & Örnek boyut & 1 \\
\hline Etki & 1 & Kurumsal kar ölçümü & 1 \\
\hline
\end{tabular}


Ek 2 (Devam). Yabancı Makalelerde Ele Alınan Anahtar Kavramlar

\begin{tabular}{|c|c|c|c|}
\hline Önemli olmak & 1 & Banka dolandırıcılığ 1 & 1 \\
\hline Sabit efekt modeli & 1 & Spread (Finans) & 1 \\
\hline CLSA (Şirket) & 1 & Yorumları denetleme & 1 \\
\hline Şirket karları & 1 & Kursal gelişim & 1 \\
\hline Organizasyon gücü & 1 & Araştırma finansmanı & 1 \\
\hline Panel analizi & 1 & Çevre, Koruma ve Yaban Hayatı Organizasyonları & 1 \\
\hline Şirket kültürü & 1 & Stok bölme & 1 \\
\hline Endonezya & 1 & Depresyonlar (Ekonomi) & 1 \\
\hline Sürdürülebilir kalkınma raporlaması & 1 & Durgunluklar & 1 \\
\hline Doğu Asya & 1 & Fiyat kazanç oranı & 1 \\
\hline Stok transferi & 1 & Adli ekonomi & 1 \\
\hline Organizasyonel etkinlik & 1 & Tezgah üstü piyasalar & 1 \\
\hline Pakistan Menkul Kıymetler Borsası Ltd. & 1 & Varlik & 1 \\
\hline Banka hisseleri & 1 & Ticaret Büyük Britanya & 1 \\
\hline Kurumsal reform & 1 & Kısa vadeli planlama & 1 \\
\hline $\begin{array}{l}\text { Diğer Tüm Mesleki, Bilimsel ve Teknik } \\
\text { Hizmetler }\end{array}$ & 1 & Malezya & 1 \\
\hline Düzenleyici reform & 1 & Kamu çıkar grupları & 1 \\
\hline Farkliliklar & 1 & Aktivizm & 1 \\
\hline Nicel araştırma & 1 & Kamu sermayesine özel yatırımlar & 1 \\
\hline Endüstriler & 1 & Özel soruşturma hizmetleri & 1 \\
\hline Adli muhasebe & 1 & Soruşturma Hizmetleri & 1 \\
\hline Yapay zeka & 1 & Devamsızlık izni & 1 \\
\hline Makine öğrenme & 1 & Çalışan tatilleri & 1 \\
\hline Sosyal bilimler eğitimi & 1 & Eğitim kazanımı araştırması & 1 \\
\hline Almanya & 1 & Organizasyon şemaları & 1 \\
\hline İstatistik & 1 & Kuzey Amerika & 1 \\
\hline Risk & 1 & Çalışanlar & 1 \\
\hline Tayvan & 1 & Vasıflı işgücü & 1 \\
\hline Hisse senedi fiyat endeksleri & 1 & Kredi Yönetimi & 1 \\
\hline Etkinlik çalışması (Finans) & 1 & Bugünkü Değer & 1 \\
\hline Menkul kiymet ticareti & 1 & Makul olmayan tazminat & 1 \\
\hline Hazine bonoları & 1 & Paydaş teorisi & 1 \\
\hline Avrupa & 1 & Petrol satışları ve fiyatları & 1 \\
\hline Sistemik risk (Finans) & 1 & Granger nedensellik testi & 1 \\
\hline Yasal uyum & 1 & Uluslararası Ticaret & 1 \\
\hline Menkul kıymet işlem hacmi & 1 & Lombard kredileri & 1 \\
\hline İspanya & 1 & Kredi anlaşmaları & 1 \\
\hline Sosyal Hizmetler & 1 & Vadeli krediler & 1 \\
\hline Etkin piyasa teorisi & 1 & Karar vermenin ekonomik yönleri & 1 \\
\hline Ekonomik sistemler & 1 & İşletme sermayesi & 1 \\
\hline $\begin{array}{l}\text { Diğer Tüm Mesleki, Bilimsel ve Teknik } \\
\text { Hizmetler }\end{array}$ & 1 & Petrol Dökme İstasyonları ve Terminalleri & 1 \\
\hline Şirketler & 1 & Ham Petrol Boru Hattı Taşımacılığ & 1 \\
\hline NASDAQ Borsas1 & 1 & Ekonomik yap1 & 1 \\
\hline Ekonomik tarih & 1 & Ham Petrol ve Doğal Gaz Çıkarma & 1 \\
\hline Bahreyn & 1 & Toplam Kalite Yönetimi & 1 \\
\hline Ekonomik gelişme & 1 & Kitap/pazar oranı & 1 \\
\hline Yatırım Yönetimi & 1 & İşletme şirketleri & 1 \\
\hline Ekonomik aktivite & 1 & Diğer Holding Şirketlerinin Ofisleri & 1 \\
\hline İş & 1 & Hipotez & 1 \\
\hline Yasal yükümlülük & 1 & Kiralama & 1 \\
\hline Finansallaşma & 1 & Sistem entegrasyonu & 1 \\
\hline Kurumsal yönetim yasaları & 1 & Bilgi Teknolojisi & 1 \\
\hline ç1kar çatışması & 1 & Bilgi Yönetimi & 1 \\
\hline Kamu hoşnutsuzluğu & 1 & Finansal araçlar & 1 \\
\hline Yönetim Kurulu Başkanı & 1 & Bilgisayar Sistemleri Tasarım Hizmetleri & 1 \\
\hline
\end{tabular}


Ek 2 (Devam). Yabancı Makalelerde Ele Alınan Anahtar Kavramlar

\begin{tabular}{|c|c|c|c|}
\hline Endüstriyel kümeler & 1 & Şirket kültürü & 1 \\
\hline Örgütsel yap1 & 1 & Baş finans görevlileri & 1 \\
\hline Ç1kar çatışması & 1 & siyasi yolsuzluk & 1 \\
\hline Özel sermaye & 1 & Banka kredileri & 1 \\
\hline Girişimcilik & 1 & kurumsal muhasebe & 1 \\
\hline Yöneticilerin değerlendirmesi & 1 & Mülk edinimi & 1 \\
\hline İnternet endüstrisi & 1 & Satın almalar & 1 \\
\hline Kurumsal imaj & 1 & Konut binaları ve konutların kiraya verenleri & 1 \\
\hline Borçlu ve alacaklı & 1 & $\begin{array}{l}\text { Konut Dışı Binaların Kiraya Verenleri (Mini Depolar } \\
\text { hariç) }\end{array}$ & 1 \\
\hline Borç finansmanı (Şirketler & 1 & Gayrimenkul yatırım fonu & 1 \\
\hline Kurumsal borç & 1 & Borç finansmanı (Şirketler) & 1 \\
\hline Kurumların denetimi & 1 & Vergi oranları & 1 \\
\hline Denetim ücretleri & 1 & Dağılım (Ekonomik teori) & 1 \\
\hline Tazminat (Hukuk) & 1 & Seçenekler (Finans) & 1 \\
\hline Küçük İşletme Güvenini Seçme & 1 & Mülkiyet hakları & 1 \\
\hline Bulaşma (Sosyal psikoloji) & 1 & Yönetim Bilimi & 1 \\
\hline Özel şirketler & 1 & Sendikasyon kredileri & 1 \\
\hline Kar paylaşımı & 1 & İnsan hakları & 1 \\
\hline Kampanya fonları & 1 & Özel sermaye fonu & 1 \\
\hline Siyasi Örgütler & 1 & İş dünyasındaki yenilikler & 1 \\
\hline Kapitalizm & 1 & Sosyal değerler & 1 \\
\hline Hizmet kalitesi & 1 & Küreselleşme & 1 \\
\hline Ekonomik İşbirliği ve Kalkınma Örgütü & 1 & Hisse senedi sertifikaları & 1 \\
\hline Uluslararası ve diğer bölge dışı kamu yönetimi & 1 & Döviz kurlar1 & 1 \\
\hline Uluslararası İlişkiler & 1 & Uyum iyiliği testleri & 1 \\
\hline Çimento Endüstrileri & 1 & Enflasyona Endeksli Tahviller & 1 \\
\hline Çimento İmalatı & 1 & İş memnuniyeti & 1 \\
\hline Kurumlar Vergileri & 1 & Maddi olmayan duran varlıkların değerlemesi & 1 \\
\hline Borç/özkaynak oranı & 1 & İş tatmini yazını & 1 \\
\hline Çalışan stok seçenekleri & 1 & Finansal vadeli işlemler & 1 \\
\hline Bankacılık yasaları & 1 & İş tatmini testi & 1 \\
\hline İş modelleri & 1 & Emtia Sözleşmeleri Aracılığ1 & 1 \\
\hline Düzenleme & 1 & İşletmenin sosyal sorumluluğu & 1 \\
\hline $\begin{array}{l}\text { Muhtelif Ticari Sektörlerin Ruhsatlandırılması ve } \\
\text { Denetimi }\end{array}$ & 1 & Ekonomik tahmin & 1 \\
\hline Örgütsel yap1 & 1 & Zaman serisi analizi & 1 \\
\hline İş araştırması & 1 & Sağlam kontrol & 1 \\
\hline Alg1 & 1 & Diğer tüm çeşitli fonlar ve finansal araçlar & 1 \\
\hline Yillık toplantılar & 1 & Emlak Kredisi & 1 \\
\hline Azınlık hissedarları & 1 & Kira (Ekonomik teori) & 1 \\
\hline Katılım & 1 & İş dünyasında rekabet avantaj1 & 1 \\
\hline Devlet kurumları & 1 & Sermaye gereksinimleri & 1 \\
\hline Diğer federal hükümet kamu yönetimi & 1 & Ürün farklılaştırması & 1 \\
\hline Kazanç trendleri & 1 & Stratejik iş birimleri & 1 \\
\hline Özyinelemeli bölümleme & 1 & Çok değişkenli analiz & 1 \\
\hline İstanbul Menkul Kıymetler Borsası (Kuruluş) & 1 & Sosyal ağlar & 1 \\
\hline Gayrimenkul & 1 & Temel gelir & 1 \\
\hline Singapur & 1 & Merkezilik & 1 \\
\hline Emlakçı ve Broker Ofisleri & 1 & Kamu Maliyesi Faaliyetleri & 1 \\
\hline Ürün farklılaştırması & 1 & Kazanç duyuruları & 1 \\
\hline
\end{tabular}

